\title{
Research progress of heavy metal pollution in China: Sources, analytical methods, status, and toxicity
}

\author{
HE Bin, YUN ZhaoJun, SHI JianBo \& JIANG GuiBin* \\ State Key Laboratory of Environmental Chemistry and Ecotoxicology, Research Center for Eco-Environmental Sciences, Chinese Academy of \\ Sciences, Beijing 100085, China
}

Received June 6, 2012; accepted October 8, 2012; published online November 23, 2012

\begin{abstract}
Heavy metal pollution is one of the most serious environmental problems in China and a large number of people are threatened by heavy metal pollution. Extensive damage to human organs, such as liver, kidney, digestion system, and nervous system can be caused by uptake of excess heavy metals. Heavy metals in the environment can originate from both natural and anthropogenic sources. Although contamination of heavy metals has been known to be a severe environmental problem for decades, it is still getting worse in recent years and there are few feasible approaches to resolve this problem. Due to their high toxicity, prevalent existence and persistence in the environment, lead $(\mathrm{Pb})$, mercury $(\mathrm{Hg})$, cadmium $(\mathrm{Cd})$, chromium $(\mathrm{Cr})$ and arsenic $(\mathrm{As})$ are commonly considered as the priority heavy metals which should be concerned and their emission should be controlled in China. This paper reviewed the pollution of heavy metals in China, focusing on the following four aspects: current status of heavy metal pollution in China, sources of heavy metals in China, toxicity and potential risk, and possible reduction strategies.
\end{abstract}

heavy metal, pollution, source, toxicity, environmental monitoring

Citation: He B, Yun Z J, Shi J B, et al. Research progress of heavy metal pollution in China: Sources, analytical methods, status, and toxicity. Chin Sci Bull, 2013, 58: 134-140, doi: 10.1007/s11434-012-5541-0

With the development of industrialization and urbanization, the amount of heavy metals produced and consumed in China has increased significantly. For example, the production of $\mathrm{Hg}$ was 1400 ton $(1$ ton $=1.016 \mathrm{t})$ in China, with 1920 ton of the world, in 2009 [1]. The total consumption of $\mathrm{Hg}$ increased about 40\% from 2004 to 2007, exceeding 1500 ton in 2007 [2].

As a result, the environmental pollution of heavy metals becomes more and more serious in China. Wu et al. [3] estimated that total $\mathrm{Hg}$ emissions from all anthropogenic sources increased at an average annual rate of $2.9 \%$ during the period 1995 to 2003, reaching $696( \pm 307)$ ton in 2003. There are more than 329000 ton of chromic salt produced by 25 companies every year, accompanying with 450000 ton of $\mathrm{Cr}$ residue [4]. More than thirty incidents caused by heavy metal pollution have been reported since 2009. During an investigation conducted in 2010 , elevated $\mathrm{Pb}$ was

*Corresponding author (email: gbjiang@ @rcees.ac.cn) observed in human blood in many places of China, such as Dafeng of Jiangsu Province, Longchang of Sichuan Province, Jiahe of Hunan Province, Guazhou of Gansu Province, Congyang of Hubei Province and Huaining of Anhui Province. About 5000 ton $\mathrm{Cr}$ residue was placed along the riverside of Nanpanjiang, Yunnan Province for 15 years, causing high concentration of $\mathrm{Cr}(\mathrm{VI})$ in the river (about 2000 times higher than the national standard) [4].

According to the sustainable development strategy of China, prevention and control of heavy metal pollution have been decided as one of the key goals in the China's "12th 5-Year Planning" (2011-2015). A specific project named "the 12th 5-Year Planing for Comprehensive Prevention and Control of Heavy Metal Pollution" was also issued by Chinese government in 2011. Due to their high toxicity, prevalent existence and persistence, five heavy metals, including $\mathrm{Pb}, \mathrm{Hg}, \mathrm{Cd}, \mathrm{Cr}$ and $\mathrm{As}$, were chosen as priority control metals. Fourteen provinces and autonomous regions were chosen as the priority control regions, including Inner 
Mongolia Autonomous Region, Jiangsu Province, Zhejiang Province, Jiangxi Province, and Henan Province. In addition, 4452 companies were put on a priority list for monitoring.

As a large number of metals and metalloids fall in the group of "heavy metals", it is really difficult to give a comprehensive view of pollution of all heavy metals in China. Therefore, this review focuses on the five priority control metals in China. The sources, toxicity, pollution status of these heavy metals were clarified. Some elimination strategies, considerations and perspectives for the future study and management were also discussed.

\section{Sources}

The sources of heavy metals in the environment consist of two categories: natural sources and anthropogenic sources.

\subsection{Natural sources of heavy metals}

Natural sources include volcanoes, degradation of minerals and forest fires, evaporation from soil and water surfaces. The natural heavy metal emissions must be considered as a part of local and global environment. About $1.72 \times 10^{7} \mathrm{~kg}$ As was released from volcanic eruptions every year, while the earth crust was estimated to contain $4.01 \times 10^{16} \mathrm{~kg} \mathrm{As}$, and other $4.87 \times 10^{6} \mathrm{~kg}$ was released from the eruption of submarine volcanoes [5].

In some areas of China, concentrations of heavy metals in the earth crust are naturally elevated, such as high concentrations of As in Shanxi Province and Inner Mongolia Autonomous Region, which contribute to elevated concentrations of related heavy metals in those areas.

\subsection{Anthropogenic sources of heavy metals}

Compared with natural sources, anthropogenic sources are commonly considered as the major causes for the increasing heavy metal pollution in the environment. The anthropo- genic sources can be divided into three groups:

(1) Releases from usage of heavy metals impurities, such as coal-fired power and heat production, mining and other metallurgic activities;

(2) Releases from intentional extraction and use of heavy metals, such as heavy metal mining, leather production, electroplating production, and manufacture of products containing heavy metals;

(3) Releases from waste incineration, landfills etc. Wu et al. [3] assessed that the total $\mathrm{Hg}$ emission in China was up to 695.6 ton in the year of 2003, most of which were from nonferrous metal smelting and coal consumption (Figure 1). A survey by United Nations in 1970 showed that 18050 ton of $\mathrm{Pb}$ was released to the atmosphere, most of which were released by oil consumption, dust emissions and gasoline additives.

\section{Analytical methods for the monitoring of heavy metal pollution}

\subsection{Total concentrations of heavy metals}

A large number of methods have been developed and applied in the determination of heavy metals in environmental and biological samples, such as flame atomic absorption spectrometry (FAAS), graphite furnace atomic absorption spectrometry (GFAAS), atomic fluorescence spectrometry (AFS), and so on. Inductively coupled plasma mass spectrometry (ICP-MS) and inductively coupled plasma atomic emission spectrometry (ICP-AES) are more and more often used in this field due to their advantages of simultaneous detection of multiple elements, short analysis time, high throughput and less sample consumption. Especially, the ICP-MS has more merits such as high sensitivity, wide linear range and strong anti-interference.

\subsection{Speciation of heavy metals}

The toxicity of heavy metals depends on their chemical
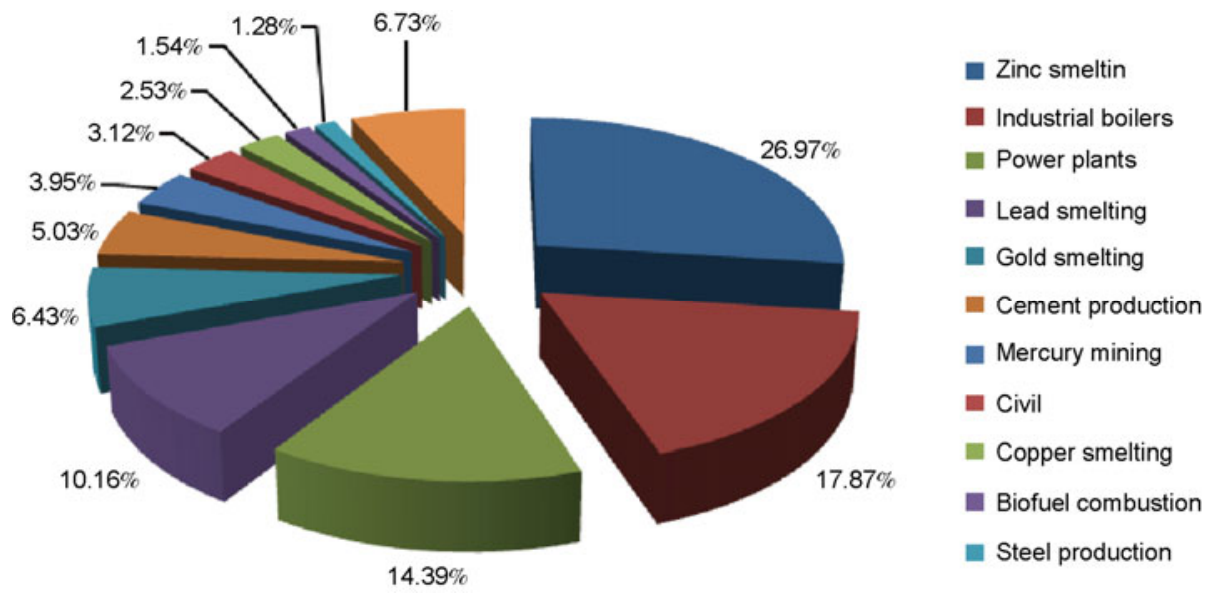

Figure 1 Contribution of various sources to $\mathrm{Hg}$ emissions in China, 2003 [3]. 
forms. Studies showed that the organic Hg compounds, especially methylmercury, are more toxic than inorganic $\mathrm{Hg}$. On the contrary, organic As species are less toxic than inorganic As compounds. The toxicity of organotin compounds depends on the nature and the length and number of the side chain of alkyl groups. Therefore, it is necessary to distinguish the species of heavy metals due to their different properties and toxicity. Speciation of heavy metals can be performed with electrical analysis, spectrometry analysis, instrumental neutron activation analysis (INAA), chromatographic analysis and hyphenated methods. Hyphenated methods have been widely applied in speciation analysis of $\mathrm{Hg}$ [6], Cr [7], As [8], Sn [9] and other heavy metals in environmental samples with vast development foreground.

\subsection{Biomonitoring of heavy metals}

Biomonitoring can offer an appealing tool for the assessment of heavy metal pollution and toxicity in the environment and biosphere [10]. Chemical analysis of the environment matrices is the most direct approach to reveal the status of heavy metal pollution in the environment, while it affords the insufficient evidence on the integrated influence and possible toxicity on the organisms and ecosystem. Biomonitoring which based on sampling and analysis of an individual organism's tissues and fluids can complement chemical analysis. Fu et al. [11] investigated the heavy metal contents in rice samples from a typical E-waste recycling area in southeast China. By comparing with the provisional tolerable weekly intakes for heavy metals defined by World Health Organization (WHO), they concluded that long term consumption of local rice might pose high risk of heavy metal exposure to consumers. Blood, urine, saliva, fingernail and hair are usually applied as biomarkers in evaluating the potential risk of heavy metals to human health [12-14].

\section{Heavy metal pollution status}

The pollution status of heavy metals is serious in China $[3,15]$. Some of the data could be found in the earlier reviews, such as heavy metal contamination in the urban soils [16], estuarine and coastal environments [17] of China. In some regions of China, eating food contaminated by heavy metals or drinking the ground water without any purification process could cause high risk of heavy metal exposure. Many incidents have been reported because of illegal or unsafe mining, smelting and use of metals.

\subsection{Lead}

The concentration of $\mathrm{Pb}$ in the urban atmosphere, such as Beijing and Tianjin, decreased in recent years due to the use of $\mathrm{Pb}$ free gasoline, although the $\mathrm{Pb}$ content is still at a high level, ranging from 100 to $180 \mathrm{ng} \mathrm{m}^{-3}[18,19]$. Soils on the sides of highway and some farmlands are vulnerable to be polluted by $\mathrm{Pb}$ because of traffic emission and waste water irrigation. The soil might be polluted by $\mathrm{Pb}$ if the distance between soil and the highway was less than $50 \mathrm{~m}$, while the $\mathrm{Pb}$ concentrations was just the same as the background level when the distance of them was more than $150 \mathrm{~m}$ [20]. Besides the nature of soil, the distribution of $\mathrm{Pb}$ in the roadside soil can be affected by traffic flow, terrain, greenbelts and weather conditions.

Generally, the concentrations of $\mathrm{Pb}$ in the roadside soil would be significantly higher than the park, while the $\mathrm{Pb}$ level of industrial area is much higher than the residential area and scenic resort. Studies showed that the $\mathrm{Pb}$ concentrations of farmland soil irrigated by waste water were elevated significantly [21], about 4.53 times of the environmental background values. Qi et al. [22] investigated the blood $\mathrm{Pb}$ level of 6502 children (3-5 year old) living in the urban areas of China. The results showed that mean blood $\mathrm{Pb}$ level was $88.3 \mathrm{mg} \mathrm{L}^{-1}$ for the children, and $29.9 \%$ of the children's blood $\mathrm{Pb}$ level exceeded $100 \mathrm{mg} \mathrm{L}^{-1}$, which is the safety concentration of childhood blood $\mathrm{Pb}$ by American Centers for Disease Control and Prevention's advisory committee. The data indicated that blood $\mathrm{Pb}$ levels of children in China should call for special concerns by government and the society.

\subsection{Mercury}

Guizhou, Guangdong, Shanxi and Liaoning provinces are the most polluted areas by $\mathrm{Hg}$ in China. Guizhou Province is known as one of the world's biggest $\mathrm{Hg}$ production regions, and it is recognized as a heavily $\mathrm{Hg}$-polluted area in China due to both the geochemical characteristics and human activities. The total reserves of cinnabar deposits in Guizhou reached 80000 ton of metal $\mathrm{Hg}$, and represented $80 \%$ of the total in China [23]. The highest Hg concentration in the surface water of Guizhou Province was up to $10580 \mathrm{ng} \mathrm{L}^{-1}$ [24]. Concentrations of total $\mathrm{Hg}$ and methylmercury in riparian soils from mined areas ranged from 5.1 to $790 \mathrm{mg} \mathrm{kg}^{-1}$ and 0.13 to $15 \mathrm{ng} \mathrm{g}^{-1}$, respectively [25,26]. The total gaseous $\mathrm{Hg}$ concentrations in the ambient air around the Wanshan mining area in Guizhou Province ranged from 11.7 to $1101.8 \mathrm{ng} \mathrm{m}^{-3}$ [27]. The concentration of $\mathrm{Hg}$ in rice grains could reach up to $569 \mathrm{ng} \mathrm{g}^{-1}$ of total $\mathrm{Hg}$, of which $145 \mathrm{ng} \mathrm{g}^{-1}$ was in methylmercury form. This indicated that intake of $\mathrm{Hg}$ polluted rice was also a potential route of $\mathrm{Hg}$ exposure [24].

The total gaseous $\mathrm{Hg}$ concentrations in Guiyang, Guizhou Province ranged from 1.70 to $146.75 \mathrm{ng} \mathrm{m}^{-3}$ and the average concentration was $7.39 \mathrm{ng} \mathrm{m}^{-3}$, which was significantly higher than the global background of approximately 1.5-2.0 $\mathrm{ng} \mathrm{m}^{-3}$ [28]. The level of $\mathrm{Hg}$ in the atmosphere could be significantly affected by the season and the weather. Generally, the total gaseous $\mathrm{Hg}$ concentrations in winter were much higher than those in summer because of coal 
combustion [29-31].

Soil is an important source and sink of $\mathrm{Hg}$. The $\mathrm{Hg}$ in soil is mainly from the soil matrix itself, dry and wet atmospheric deposition, usage of fertilizer and pesticides, waste water irrigation and $\mathrm{Hg}$-containing waste. According to an investigation conducted by China National Environmental Monitoring Centre (CNEMC) in 1990 [32], the national average concentration of $\mathrm{Hg}$ in the surface soil of China was $0.065 \mathrm{mg} \mathrm{kg}^{-1}$. Our ongoing study shows that high concentrations of $\mathrm{Hg}$ in soils have been found in some regions in recent years.

The concentrations of $\mathrm{Hg}$ in water samples, including seawater, river water, and lake water etc, could also be found in some literatures. Because there is no systematic investigation on the water environment, and the spatial and temporal distribution of $\mathrm{Hg}$ in water changes ceaselessly, it is very hard to give an overall evaluation on the $\mathrm{Hg}$ concentrations in water system. The reported concentrations of $\mathrm{Hg}$ in the large rivers are generally high [33-35]. However, reservoirs are relatively less impacted.

\subsection{Cadmium}

Cd pollution incidents occurred occasionally in recent years in China. Tang et al. [36] evaluated Cd pollution and its potential risk in paddy soils around an industrial park in Xiangtan, Hunan province. Results showed that the concentration range of $\mathrm{Cd}$ in soil were $1.27-4.22 \mathrm{mg} \mathrm{kg}^{-1}$, indicating those paddy soils were suffered from heavy $\mathrm{Cd}$ contamination. Zheng et al. [37] investigated Cd concentrations of 595 soil samples which were sampled from different regions of Beijing, including vegetable field, paddy field, orchard, greenbelt, corn field, and natural soil. Compared with the background concentration, the accumulation of $\mathrm{Cd}$ in the vegetable field, paddy field and orchard was significant. This indicates that industrial activities, traffic and landfill could affect the concentrations of $\mathrm{Cd}$ in soil. From the investigation of $\mathrm{Cd}$ pollution in vegetable land, atmospheric deposition found to be the main source of $\mathrm{Cd}$ in soil [38].

Comparing with water, sediment showed significant accumulation of Cd $[39,40]$, which indicated that the sediment would reduce the water pollution level. However, it should be noted that the high concentration of $\mathrm{Cd}$ in sediment could cause secondary pollution and the environmental risk should be concerned.

\subsection{Chromium}

China produces the most abundant $\mathrm{Cr}$ waste in the world every year, posing high risk to the ambient environment and the human health. The migration of $\mathrm{Cr}(\mathrm{VI})$ was found all around the $\mathrm{Cr}$ slag heap. $\mathrm{Cr}(\mathrm{VI})$ concentrations of soil leaching solution was found to have an inverse relationship with the distance to the $\mathrm{Cr}$ residue, while the waste could affect about $350 \mathrm{~m}$ of the downwind side [41]. Besides migrating to the surrounding areas, $\mathrm{Cr}(\mathrm{VI})$ can pollute the underground waters as well. Studies about $\mathrm{Cr}$ pollution at the mining and plateau areas showed the similar results $[42,43]$.

Concentrations of $\mathrm{Cr}$ in natural waters vary very large in China. Chen et al. [44] analyzed the concentrations of $\mathrm{Cr}$ in the water of Taihu Lake, east China, and assessed the associated ecological risk. $\mathrm{Cr}$ could be detected in all the water samples, which ranged from $31.76 \mathrm{ng} \mathrm{mL}^{-1}$ to 75.50 $\mathrm{ng} \mathrm{mL} \mathrm{m}^{-1}$, and the mean concentration was $40.04 \mathrm{ng} \mathrm{mL}^{-1}$. The aquatic organisms in Taihu Lake suffered low risk from $\mathrm{Cr}$ pollution. Wang et al. [45] studied the distribution of $\mathrm{Cr}(\mathrm{VI})$ and its migration characteristics in Weihe river in Shaanxi province. Results showed that the concentrations of $\mathrm{Cr}(\mathrm{VI})$ in Weihe river increased first and then decreased along the river and might be affected by the drain outlet. The authors also found that sediment plays a significant role in reducing the concentration of $\mathrm{Cr}(\mathrm{VI})$. Qu et al. [46] found that only little amount of $\mathrm{Cr}$ was detected in the water of Zhanjiang seaport and the concentrations of $\mathrm{Cr}$ were affected by the running ships.

\subsection{Arsenic}

Chronic endemic asenicosis have been reported frequently in past several decades, especially in Xinjiang Uygur Autonomous Region, Inner Mongolia Autonomous Region, Ningxia Hui Autonomous Region and Shanxi Province. Concentrations of As in the underground water of most affected provinces in China ranged from $220 \mathrm{ng} \mathrm{mL}^{-1}$ to 2000 $\mathrm{ng} \mathrm{mL} \mathrm{m}^{-1}$, while the highest concentration could be 4440 $\mathrm{ng} \mathrm{mL} \mathrm{m}^{-1}$ [47]. Chronic asenicosis is a newly-emerged public health issue and about 3 million people were estimated to be at the risk of high As exposure from drinking water in China, while most of them were in the countryside areas. A survey on drinking water in polluted areas showed that about $10.2 \%$ of 39514 wells from 713 villages were unsafe, in which the concentrations of As were higher than 50 ng $\mathrm{mL}^{-1}[48]$.

China is one of the world's largest coal producers and consumers and $75 \%$ of energy comes from coal combustion. Asenicosis caused by coal combustion have been found in China, especially in Guizhou Province. The contents of As in coals collected from the main coal mines in northeastern, northern and eastern China ranged from 55.7 to $156.7 \mathrm{mg}$ $\mathrm{kg}^{-1}$ [49]. Local residents commonly use the As-rich coal in open oven, which would pollute the indoor air and food. The concentrations of As in kitchen air, dried corn and hot peppers were $160-760 \mu \mathrm{g} \mathrm{m}^{-3}, 1.52-11.3 \mathrm{mg} \mathrm{kg}^{-1}$ and $52.5-$ $1090 \mathrm{mg} \mathrm{kg}^{-1}$, respectively; for this type of asenicosis, the population at risk was about 200000 and more than 2300 patients have been diagnosed [48].

Human activities, such as mining and acid production, can also cause serious As pollution. Studies around an abandoned tungsten mine and industrial districts showed 
that the surrounding soil and ground water were polluted by As in varying degrees, and the rice contained high levels of As (0.15-1.09 mg kg-1 and 0.5-7.5 mg kg-1, respectively), indicating that humans might suffer a high health risk of As $[14,50]$.

\subsection{Tin}

Both seawater and fresh water can be polluted by Sn, especially the water around coast, port and river trade terminal. The highest concentration of tributyltin (TBT) in water samples collected from different sites of China could reach up to $977 \mathrm{ng}(\mathrm{Sn}) \mathrm{L}^{-1}$ [51]. The concentrations of butyltin (BTs) decreased with the increase of the distance from the coast because of reduced input, water flow and dilution. Relatively high levels of dibutyltin (DBT) and TBT were found in coastal waters of Bohai Bay [52]. The TBT in sediment of three harbors (Xiamen, Shantou, and Huiyang) along southeast coast ranged from 0.3 to $174.7 \mathrm{ng} \mathrm{g}^{-1}$ [53], indicating that these areas are highly polluted by TBT. Elevated organotin compounds were also detected in areas surrounding three gorges reservior [54].

\section{Toxicity}

Heavy metals from natural and anthropogenic sources could be accumulated by food chain in water, air and soil. Exposure to heavy metals by eating, drinking, touching, and breathing are the main routes of toxicosis for human beings and arose various threat to human health [55-59] (showed in Table 1). The toxicity of heavy metals could be divided into several categories according to the target organs.

\subsection{Renal effects}

The kidney is a critical organ accumulating heavy metals. High exposure to $\mathrm{Pb}$ could damage the renal poximal tubule and glomerular cells, disorder the tubular reabsorption, even cause $\mathrm{Pb}$ poisoning nephropathy, such as nephrogenic hypertension [60]. Elemental $\mathrm{Hg}$ can be oxidized in body tissues to the inorganic divalent form. The kidney accumulates more divalent $\mathrm{Hg}$ than other tissues. High exposure to $\mathrm{Hg}$ may cause glomerulonephritis with proteinuria and nephritic syndrome. Effects on the renal tubules, which would increase excretion of low molecular proteins, had been found at low level of $\mathrm{Hg}$ exposure, and may constitute the earliest biological effect.

\subsection{Gastrointestinal (digestive system) effects}

Intake of heavy metals could stimulate the digestive system, accompanying with symptoms such as nausea, vomiting, diarrhea, abdominal cramps and so on. $\mathrm{Pb}$ could disorder the gastrointestinal function by inhibiting the pancreas and increasing the secretion of the salivary gland and gastric gland, even cause intractable constipation [60].

\subsection{Neurological effects}

Previous studies reported that both accidental and chronical exposure to high concentration of $\mathrm{Hg}$ vapor can significantly affect cognitive, sensory, personality and motor functions of human. In general, these symptoms will subside after removal from exposure. The toxicity of methylmercury is much higher than that of inorganic $\mathrm{Hg}$. Its effects on the developing nervous system in unborn and newborn children have been well-documented by conducting various human and animal studies. Such effects can take place even at exposure levels where the mother (through whom the children receive the $\mathrm{Hg}$ ) remains healthy or has only minor symptoms associated with $\mathrm{Hg}$ exposure [61,62]. A study of about 900 Faroese children, whose parents were exposed to methylmercury mainly from pilot whale meat, showed that prenatal exposure to methylmercury would result in neuropsychological deficits at 7 years of age $[63,64]$. Attention, memory and language seemed to be the most vulnerable brain functions, while visual function and executive were less affected by increased $\mathrm{Hg}$ exposure.

\subsection{Cancer}

Lots of studies focused on the causes of death in populations in Minamata with high exposures to methylmercury. Excess mortality from cancer of the liver and of the oesophagus was found in the area with the highest exposure, together with an increased risk for chronic liver disease and cirrhosis [65]. The risk of skin cancer, lung cancer and bladder cancer also increased in the region where the people suffered from long term and chronic exposure for As [47].

\subsection{Other effects}

Exposures to high concentrations of heavy metals could cause the disfunction of respiratory system, cardiovascular system, immune system and reproductive system. Intake of $\mathrm{Pb}$ could induce anemia by inhibiting the formation of hemoglobin, especially for the children. The risk of stomatitis, gingivitis, perforation of nasal septum, skin ulcers for people who were long term exposure to $\mathrm{Cr}$ (VI) was much higher than the other people. A survey about a $\mathrm{Cr}$ plating workshop indicated that half of the workers who engaged in electroplating operations got severe Cr-rhinopathy [66].

\section{Conclusions and perspectives}

Heavy metal pollution is one of the most serious environmental problems in China, which poses great threat to human beings. Besides the natural sources, intentional and 
Table 1 The toxicity of heavy metals

\begin{tabular}{|c|c|c|c|c|c|c|c|}
\hline \multirow[b]{2}{*}{ Variable } & \multirow[b]{2}{*}{ Inorganic $\mathrm{Pb}$ [55] } & \multicolumn{3}{|c|}{$\mathrm{Hg}[56]$} & \multirow{2}{*}{$\begin{array}{c}\text { Inorganic } \\
\text { Cd [57] }\end{array}$} & \multirow[b]{2}{*}{$\mathrm{Cr}(\mathrm{VI})[58]$} & \multirow[b]{2}{*}{ Inorganic As [59] } \\
\hline & & $\mathrm{Hg}$ vapor & $\begin{array}{c}\text { Inorganic } \\
\text { divalent } \mathrm{Hg}\end{array}$ & Methylmercury & & & \\
\hline Symptom & $\begin{array}{l}\text { Microcytic anemia, } \\
\text { encephalopathy (mainly } \\
\text { in children), peripheral } \\
\text { neuropathy (mainly in } \\
\text { adults), tubular damage } \\
\text { in acute intoxication, } \\
\text { interstitial-glomerular } \\
\text { fibrosis and atrophy in } \\
\text { chronic intoxication }\end{array}$ & $\begin{array}{l}\text { Proteinuria, } \\
\text { peripheral } \\
\text { neuropathy, } \\
\text { erethism, and } \\
\text { tremor } \\
\left(>500 \mu \mathrm{g} \mathrm{m}^{-3}\right. \\
\text { of air) }\end{array}$ & $\begin{array}{l}\text { Stomatitis, } \\
\text { gastroenteritis, } \\
\text { urticaria, } \\
\text { proteinuria, } \\
\text { tubular necrosis }\end{array}$ & $\begin{array}{l}\text { Paresthesia, } \\
\text { ataxia, visual } \\
\text { and hearing loss } \\
\text { (>200 } \mu \mathrm{g} \mathrm{L}^{-1} \text { of } \\
\text { blood) }\end{array}$ & $\begin{array}{l}\text { Chronic } \\
\text { nephropathy } \\
\text { characterized by } \\
\text { proximal tubular } \\
\text { necrosis and } \\
\text { proteinurea, } \\
\text { lung cancer }\end{array}$ & $\begin{array}{l}\text { Lung cancer, } \\
\text { stomatitis, } \\
\text { gingivitis, } \\
\text { perforation of } \\
\text { nasal septum, } \\
\text { skin ulcers }\end{array}$ & $\begin{array}{l}\text { Projective vomiting, } \\
\text { profuse diarrhea and } \\
\text { hematuria (acute As } \\
\text { poisoning); conjuncti- } \\
\text { vitis, skin cancer, } \\
\text { hepatomegaly and } \\
\text { splenomegaly (long- } \\
\text { term exposure to As) }\end{array}$ \\
\hline
\end{tabular}

unintentional anthropogenic releases are important sources of heavy metals. Exposure to excess heavy metals may increase human health risk by affecting the digestive system, neurological system, cardiovascular system and immune system, or increasing cancer risk.

In order to fully understand the heavy metal pollution status, a comprehensive investigation of heavy metals should be performed in China. More detailed epidemiological studies on the potential risks of heavy metals should be carried out.

Minimization and elimination of heavy metals are far more desirable compared to other pollution control strategies. These aims could be achieved by reducing the use of heavy metal-containing items, or recycling them before discharging the pollutants to the environment. Meanwhile, various end-of-pipe methods can be used to reduce heavy metal emissions from coal combustion, landfills and other anthropogenic sources. Although deficiencies exit in practical applications, bioremediation, especially phytoremediation and microbial remediation, should be paid more and more attention due to its high efficiency and low cost.

The work was supported by the National Basic Research Program of China (2013CB430004) and the National Natural Science Foundation of China (20937002, 21120102040, 20977107, 21075130).

1 USGS. 2009 minerals yearbook, mercury (advance release). US Geological Survey, 2009

2 Jian X D, Shen Y W, Yao W, et al. Status analysis and reduction countermeasures of China's mercury supply and demand. Res Environ Sci, 2009, 788-792

3 Wu Y, Wang S X, Streets D G, et al. Trends in anthropogenic mercury emissions in China from 1995 to 2003. Environ Sci Technol, 2006, 40: 5312-5318

4 Gao Y, Xia J. Chromium contamination accident in china: Viewing environment policy of China. Environ Sci Technol, 2011, 45: 8605-8606

5 Matschullat J. Arsenic in the geosphere-A review. Sci Total Environ, 2000, 249: 297-312

6 Liang L N, Jiang G B, Liu J F, et al. Speciation analysis of mercury in seafood by using high-performance liquid chromatography on-line coupled with cold-vapor atomic fluorescence spectrometry via a post column microwave digestion. Anal Chim Acta, 2003, 477: 131-137

7 Wang H J, Du X M, Wang M, et al. Using ion-pair reversed-phase HPLC ICP-MS to simultaneously determine $\mathrm{Cr}(\mathrm{III})$ and $\mathrm{Cr}(\mathrm{VI})$ in urine of chromate workers. Talanta, 2010, 81: 1856-1860

8 He B, Fang Y, Jiang G B, et al. Optimization of the extraction for the determination of arsenic species in plant materials by high-performance liquid chromatography coupled with hydride generation atomic fluorescence spectrometry. Spectrochim Acta B, 2002, 57: 1705-1711

9 Liu J Y, Jiang G B, Zhou Q F, et al. Headspace solid-phase microextraction of butyltin species in sediments and their gas chromatographic determination. J Sep Sci, 2001, 24: 459-464

10 Zhou Q F, Zhang J B, Fu J J, et al. Biomonitoring: An appealing tool for assessment of metal pollution in the aquatic ecosystem. Anal Chim Acta, 2008, 606: 135-150

11 Fu J J, Zhou Q F, Liu J M, et al. High levels of heavy metals in rice (Oryza sativa L.) from a typical E-waste recycling area in southeast China and its potential risk to human health. Chemosphere, 2008, 71: 1269-1275

12 Wang S Q, Zhang J L. Blood lead levels in children, China. Environ Res, 2006, 101: 412-418

13 Huo X, Peng L, Xu X J, et al. Elevated blood lead levels of children in Guiyu, an electronic waste recycling town in China. Environ Health Persp, 2007, 115: 1113-1117

14 Liu C P, Luo C L, Gao Y, et al. Arsenic contamination and potential health risk implications at an abandoned tungsten mine, southern China. Environ Pollut, 2010, 158: 820-826

15 Jin Y L, Liang C K, He G L, et al. Study on distribution of endemic arsenism in China. J Hygiene, 2003, 519-540

16 Luo X S, Yu S, Zhu Y G, et al. Trace metal contamination in urban soils of China. Sci Total Environ, 2012, 421: 17-30

17 Pan K, Wang W X. Trace metal contamination in estuarine and coastal environments in China. Sci Total Environ, 2012, 421: 3-16

18 Li C W, Liang Y M, Chen Y M. Combined ultrafiltration and suspended pellets for lead removal. Sep Purif Technol, 2005, 45: 213-219

19 Wang W, Liu X D, Zhao L W, et al. Effectiveness of leaded petrol phase-out in Tianjin, China based on the aerosol lead concentration and isotope abundance ratio. Sci Total Environ, 2006, 364: 175187

20 Warren R S, Birch P. Heavy metal levels in atmospheric particulates, roadside dust and soil along a major urban highway. Sci Total Environ, 1987, 59: 253-256

21 Hu W, Wang H Y, Zha T G, et al. Soil heavy metal accumulation and 
speciation in a sewage-irrigated area along the Liangshui River, Beijing. Eco Environ, 2008, 1491-1497

22 Qi Q, Yang Y, Yao X, et al. Blood lead level of children in the urban areas in China. Chin J Epidem, 2002, 23: 162-166

23 Feng X B, Qiu G L. Mercury pollution in Guizhou, southwestern China-An overview. Sci Total Environ, 2008, 400: 227-237

24 Horvat M, Nolde N, Fajon V, et al. Total mercury, methylmercury and selenium in mercury polluted areas in the province Guizhou, China. Sci Total Environ, 2003, 304: 231-256

25 Qiu G L, Feng X B, Wang S F, et al. Mercury and methylmercury in riparian soil, sediments, mine-waste calcines, and moss from abandoned $\mathrm{Hg}$ mines in east Guizhou province, southwestern China. Appl Geochem, 2005, 20: 627-638

26 Wang S F, Feng X B, Qiu G L, et al. Characteristics of mercury exchange flux between soil and air in the heavily air-polluted area, eastern Guizhou, China. Atmos Environ, 2007, 41: 5584-5594

27 Feng X B, Sommar J, Lindqvist O, et al. Occurrence, emissions and deposition of mercury during coal combustion in the Province Guizhou, China. Water Air Soil Poll, 2002, 139: 311-324

28 Feng X B, Tang S L, Shang L H, et al. Total gaseous mercury in the atmosphere of Guiyang, P R China. Sci Total Environ, 2003, 304: 61-72

29 Fang F M, Wang Q C, Liu R H, et al. Atmospheric particulate mercury in Changchun City, China. Atmos Environ, 2001, 35: 4265-4272

30 Fang F M, Wang Q C, Li J F. Atmospheric particulate mercury concentration and its dry deposition flux in Changchun City, China. Sci Total Environ, 2001, 281: 229-236

31 Zhang Y Y, Xiu G L, Zhang D N, et al. Total gaseous mercury in ambient air of Shanghai: Its seasonal variation in relation to meteorological condition. Environ Sci Technol, 2012, 155-158

32 Wei F S, Zheng C J, Chen J S, et al. Study on the background contents on 61 elements of soils in China. Environ Sci, 1991, 12-19

33 Liu S M, Zhang J. Mercury in four north China estuaries: The Daliaohe, Yalujiang, Luanhe and Dongcunhe. Periodical Ocean Univ China, 2001, 31: 36-42

34 Wang S F, Jia Y F, Wang S Y, et al. Total mercury and monomethylmercury in water, sediments, and hydrophytes from the rivers, estuary, and bay along the Bohai Sea coast, northeastern China. Appl Geochem, 2009, 24: 1702-1711

35 Zhang Z S, Sun X J, Wang Q C, et al. Recovery from mercury contamination in the second Songhua river, China. Water Air Soil Poll, 2010, 211: 219-229

36 Tang Z, Yang R B, Lei M, et al. Risk assessment of Cd in paddy soil and rice sample collected from an industrial park of Xiangtan. J Hunan Agricult Univ, 2012, 92-95

37 Zheng Y M, Luo J F, Chen T B, et al. Cadmium accumulation in soils for different land uses in Beijing. Geographical Res, 2005, 542-548

38 Huang S S, Hua M, Jin Y, et al. Investigation of cadmium pollution and its major sources in vegetable land in the suburb of Nanjing City. J Soil Sci, 2008, 129-132

39 Xi J Z, Li C M, Wang S Y, et al. Situation and assessment of heavy metal pollution in river and mud in one city in Henan Province. $J$ Hygiene Res, 2010, 767-769

40 Li X Y, Ji H B, Zhu X F, et al. Analysis on distribution and partition of heavy metal in sediments of northern Beijing water source. Mod Agric Sci Technol, 2010, 273-277

41 Zhao G H, Chang W Y, Chen X D, et al. Analysis on chromium (VI) transportation way in the typical disposal site and primary screening of chromium tolerance plants. Environ Prot Sci, 2011, 40-43

42 Bei R T, Li F B, Wu M, et al. Study on arsenic and chromium absorption characteristics on polluted sediment of Sanchahe river in Dulong mining area. Environ Sci Technol, 2011, 10-13
43 Zhang H J, Wang X R, Chen C Y, et al. Study on the polluting property of chrome residue contaminated sites in plateau section. J Environ Engin, 2010, 915-918

44 Chen L L, Zhou B H, Xu B B, et al. Cadmium and chromium concentrations and their ecological risks in the water body of Taihu Lake, East China. J Ecol, 2011, 2290-2296

45 Wang Y Q, He L X, Ma Y G, et al. Study on distribution of chromium (VI) and its migration characters in Shaanxi district in Weihe River. J Northwest A F Univ, 2012, 129-134

46 Qu N D, Tian X L, Yi Z Q, et al. Total Zn, Cr in the water of Zhan Jiang seaport and the water quality assessment. Ocean Devel Manag, 2011, 69-73

47 Mandal B K, Suzuki K T. Arsenic round the world: A review. Talanta, 2002, 58: 201-235

48 Sun G F. Arsenic contamination and arsenicosis in China. Toxicol Appl Pharm, 2004, 198: 268-271

49 He B, Liang L, Jiang G B. Distributions of arsenic and selenium in selected Chinese coal mines. Sci Total Environ, 2002, 296: 19-26

50 Liao X Y, Chen T B, Xie H, et al. Soil As contamination and its risk assessment in areas near the industrial districts of Chenzhou City, Southern China. Environ Int, 2005, 31: 791-798

51 Jiang G B, Zhou Q F, Liu J Y, et al. Occurrence of butyltin compounds in the waters of selected lakes, rivers and coastal environments from China. Environ Pollut, 2001, 115: 81-87

52 Gao J M, Hu J Y, Wan Y, et al. Butyltin compounds distribution in the coastal waters of Bohai Bay, People's Republic of China. Bull Environ Contam Toxi, 2004, 72: 945-953

53 Huang C J, Dong Q X, Lei Z, et al. An investigation of organotin compound contamination in three harbors along southeast coast of China. Acta Oceanol Sin, 2005, 57-63

54 Gao J M, Hu J Y, Zhen H, et al. Organotin compounds in the Three Gorges Reservoir region of the Yangtze River. Bull Environ Contam Tox, 2006, 76: 155-162

55 Gerber G B, Leonard A, Jacquet P. Toxicity, mutagenicity and teratogenicity of lead. Mutat Res, 1980, 76: 115-141

56 Clarkson T W, Magos L, Myers G J. The toxicology of mercuryCurrent exposures and clinical manifestations. New Engl J Med, 2003, 349: 1731-1737

57 Waalkes M P. Cadmium carcinogenesis. Mutat Res-Fund Mol M, 2003, 533: 107-120

58 Cohen M D, Kargacin B, Klein C B, et al. Mechanisms of chromium carcinogenicity and toxicity. Crit Rev Toxicol, 1993, 23: 255-281

59 Jain C K, Ali I. Arsenic: Occurrence, toxicity and speciation techniques. Water Res, 2000, 34: 4304-4312

60 Liang Q F, Li J X, Qiu J X. Harmful effects of lead on human health. Trace Element Sci, 2003, 57-60

61 WHO/IPCS. Environmental health criteria No 101. Geneva, Switzerland, 1990,

62 Davis L E, Kornffld M, Mooney H S, et al. Methylmercury poisoning-long-term clinical, radiological, toxicological, and pathologicalStudies of an affected family. Ann Neurol, 1994, 35: 680-688

63 Grandjean P, Weihe P, White R F, et al. Cognitive deficit in 7-yearold children with prenatal exposure to methylmercury. Neurotoxicol Teratol, 1997, 19: 417-428

64 Shamlaye C F, Marsh D O, Myers G J, et al. The Seychelles child development study on neurodevelopmental outcomes in children following in utero exposure to methylmercury from a maternal fish diet: Background and demographics. Neurotoxicology, 1995, 16: 597-612

65 IARC (International Agency for Research on Cancer). IARC Monographs on the Evaluation of Carcinogenic Risks to Humans. 1993

66 Liu X H, Wang Y Y, Xia A L. Investigation of the severe rhinopathy in a chromium plating workship. J Indust Med, 2011, 137-138

Open Access This article is distributed under the terms of the Creative Commons Attribution License which permits any use, distribution, and reproduction in any medium, provided the original author(s) and source are credited. 